\title{
Dakwah Kultural Bayt al-Qur'an al-Akbar Ukiran Kayu Khas Melayu Palembang
}

Reza Pahlevi

Fakultas Dakwah dan Komunikasi

Univesitas Islam Negeri Raden Fatah Palembang, Indonesia

Email: rezapahlevi_uin@radenfatah.ac.id

\begin{abstract}
Abstrak
Penelitian ini berusaha mengungkap berbagai fenomena yang menggambarkan serangkaian kegiatan dakwah kultural Bayt al-Qur'an al-Akbar Ukiran Khas Melayu Palembang. Sehingga dapat diperoleh sejumlah informasi mengenai berbagai upaya penerapan program yang dimaksud. Penelitian ini dapat disimpulkan, pertama kontribusi Bayt al-Qur'an al-Akbar Ukiran Khas Melayu Palembang terhadap perkembangan metode dakwah kultural adalah dakwah melalui seni. Kedua, Bayt al-Qur'an al-Akbar Ukiran Khas Melayu Palembang sebagai tempat Wisata Religi yang sangat signifikan.
\end{abstract}

\begin{abstract}
This research tries to reveal the various phenomenon that describe a series of cultural propaganda activities Bayt al-Qur'an al-Akbar Ukiran Khas Melayu Palembang. In order to obtain some informations about the efforts of the implementation of the program in question. It can be concluded, the first contribution of Bayt al-Qur'an al-Akbar Ukiran Khas Melayu Palembang on the development of methods of cultural propaganda is propaganda through art. Second Bayt al-Qur'an al-Akbar Ukiran Khas Melayu Palembang as a very significant Religious Tourism.
\end{abstract}

Keywords: Dakwah, Bayt Al-Qur'an, Ukiran Kayu Khas Melayu

Dakwah kultural adalah kegiatan dakwah yang dapat dilakukan dengan menggunakan pendekatan ilmu pengetahuan, adat istiadat, kesenian, dan sebagainya. Dakwah kultural juga dapat digunakan untuk memahami agama yang

Intizar, Vol. 22, No. 1, 2016 
terdapat pada tataran empiris atau agama yang tampil dalam bentuk formal yang menggejala di masyarakat.

Pengalaman beragama yang terdapat di masyarakat tersebut diproses oleh penganutnya dari sumber agama, yaitu melalui penalaran. Misalnya, membaca kitab fiqih, maka fiqih merupakan pelaksanaan dari nash al-Qur'an maupun hadits sudah melibatkan unsur penalaran dan kemampuan manusia. Dengan demikian, agama menjadi membudaya atau membumi di tengah-tengah masyarakat. Agama yang tampil dalam bentuknya yang demikian itu berkaitan dengan kultur yang berkembang di masyarakat tempat agama berkembang. Dengan melalui pemahaman terhadap kultur tersebut seseorang akan dapat mengamalkan ajaran agama.

Salah satu bentuk dakwah kultural adalah dakwah melalui seni. Bagi pecinta karya seni, pesan dakwah jenis ini lebih banyak membuatnya berpikir tentang Allah Swt. dan makhluk-Nya, lebih daripada ketika hanya mendengar ceramah agama. Ia bisa meneteskan air mata ketika melihat sebuah lukisan pemandangan laut yang terhampar luas dengan gelombang yang menggunung dan di kejauhan terlihat seseorang yang bersujud di atas perahu kecil yang sedang terombang-ambing. ${ }^{1}$

Al-Qur'an telah menyatakan dirinya sebagai kitab petunjuk (hudan) yang dapat menuntun umat manusia ke jalan yang benar. Selain itu, ia juga berfungsi sebagai pemberi penjelasan (tibyân) terhadap segala sesuatu dan pembeda (furqân) antara kebenaran dan kebatilan. Untuk mengungkap petunjuk dan penjelasan dari al-Qur'an, telah dilakukan berbagai upaya oleh sejumlah pakar dan ulama yang berkompeten untuk melakukan penafsiran terhadap al-Qur'an, sejak masa awalnya hingga sekarang ini. Meski demikian, keindahan bahasa al-Qur'an, kedalaman maknanya serta keragaman temanya, membuat pesan-pesannya tidak pernah berkurang, apalagi habis, meski telah dikaji dari berbagai aspeknya. Keagungan dan keajaibannya selalu muncul seiring dengan perkembangan akal manusia dari masa ke masa. Kandungannya seakan tak lekang disengat panas dan tak lapuk dimakan hujan. Karena itu, upaya menghadirkan pesan-pesan al-Qur'an merupakan proses yang tidak pernah berakhir selama manusia hadir di muka bumi. $^{2}$

Al-Qur'an sejak pertama kali diturunkan telah mempesona orang-orang Arab karena daya pikatnya bagaikan sihir. Oleh karenanya, al-Qur'an adalah faktor penentu atau salah satu dari faktor penentu yang mendorong berimannya orang-orang yang beriman di masa permulaan dakwah, yaitu di hari ketika Nabi 
Muhammad Saw, masih belum memiliki daya upaya dan kekuasaan, dan di hari ketika Islam masih belum mempunyai kekuatan maupun pertahanan. ${ }^{3}$

Sedangkan membumikan al-Qur'an merupakan keniscayaan. Sebagai kitab suci terakhir, al-Qur'an harus menerobos perkembangan zaman, melintasi batas-batas geografis, dan menembus lapisan-lapisan budaya yang pluralistik, karena kandungannya selalu sejalan dengan kemaslahatan manusia. Di mana terdapat kemaslahatan, di situ ditemukan tuntunan al-Qur'an. Sebaliknya, di mana terdapat tuntunan al-Qur'an, di situ terdapat kemaslahatan.

Konsep-konsep al-Qur'an tentang keindahan dan kesenian, misalnya, tentang surga, juga sangat inspiratif. Penggambaran al-Qur'an bahwa surga itu mengalir air di bawahnya, digunakan sebagai sumber inspirasi untuk keindahan. Maka di depan bangunan Taj Mahall, misalnya, ada kolam panjang yang sebetulnya diinspirasi oleh al-Qur'an. Di kolam ini, ada air mancur yang mungkin karena terlalu mahal untuk diperlihatkan sepanjang masa, sekarang hanya dalam waktu-waktu tertentu saja air mancurnya dinyalakan. Itu adalah unsur rasa keindahan sebagai deskripsi mengenai surga (tajrî min tahtihâ al-anhâr, QS. 13: $35)$.

Tentu saja menjadikan sungai sebagai bagian dari unsur keindahan yang tinggi, perlu mempertimbangkan faktor konteks lingkungan kultural. Karena orang Arab ketika menerima al-Qur'an hidupnya di padang pasir yang tentu saja tidak ada sungainya. Oleh karena itu, dambaan kepada air, sungai, kebun, taman, dan sejenisnya, pada umat Islam tinggi sekali. Tidak heran ketika orang-orang Arab mulai mempunyai kemampuan untuk menyatakan rasa keindahan, mereka merujuk kepada hal-hal yang kira-kira seperti penggambaran surga. Di Alhamra Spanyol, misalnya, kebun atau taman itu luar biasa indahnya, di mana komponen air digunakan sebagai elemen arsitektur yang diadaptasi dari deksripsi tentang surga dalam al-Qur'an.

Seindah-indahnya Borobudur atau Prambanan, tetapi warnanya adalah warna batu, yaitu warna abu-abu. Tidak ada permainan warna di sana. Berbeda dengan bangunan-bangunan Islam yang memakai warna sebagai bagian estetika. Misalnya, banyak orang mengatakan, seindah-indah bangunan di muka bumi ini, sampai sekarang, adalah Taj Mahall. Selain bentuk dan kecanggihan di dalam pelukisan kaligrafi dan arabesnya, permainan warna juga digunakan di situ. Warna putih yang dipadukan dengan lingkungan di tepi sungai menebarkan keindahan yang luar biasa, dan pada saat Bulan Purnama menjadi pemandangan yang sangat menakjubkan. Sayang, sekarang ada polusi dari cerobong-cerobong pabrik 
sehingga warnanya mulai kabur. Selain di Taj Mahall, permainan warna selain keindahan bentuk juga sangat terlihat pada bangunan-bangunan masjid di Iran, Istana Alhamra di Granada, atau Masjid Cordova.

Namun demikian, al-Qur'an tidak boleh ditonjolkan sebagai barang antik yang harus dimitoskan. Karena hal itu, dapat menciptakan jarak antara al-Qur,an dengan realitas sosial. Al-Qur'an di satu pihak diidealisasi sebagai sistem nilai sakral dan transendental, sementara di pihak lain, realitas sosial yang harus dibimbingnya begitu pragmatis, rasional, dan materialistis. Seolah-olah, nilai-nilai al-Qur'an yang dialamatkan untuk manusia berhadap-hadapan dengan realitas itu. ${ }^{4}$

Perjalanan bangsa ini sangat erat kaitannya dengan sejarah dan kebudayaan Islam. Dalam konteks sosial budaya, fungsi pengembangan kesenian bernafaskan Islam adalah untuk menjalin silaturrahmi, khususunya dalam hal mengajak sesama manusia untuk mendekatkan diri kepada Allah melalui cara yang bijak dan baik.

Pengembangan kesenian bernafaskan Islam itulah disebut sacret art (seni suci). Dan semua kesenian tradisional, asalnya berkisar di sekitar kesucian itu. Orang Islam tidak bisa mengekspresikan itu, dengan menjadikan Tuhan sebagai objek seni. Tetapi bukan berarti tidak ada seni suci dalam Islam. Positifnya, karena Tuhan tidak bisa digambar, umat Islam pun melihat kepada hal-hal yang abstrak, seperti seni geometris yang sangat banyak kaitannya dengan matematika, maka seni Islam menjadi sangat rasional. ${ }^{5}$

Di masjid al-Haram, misalnya, banyak bentuk-bentuk yang bersegi delapan. Ini contoh arabesk. Disebut arabesk karena seni itu memang khas Arab, tidak ada pada bangsa lain. Tetapi sebetulnya juga khas Islam, karena telah dipergunakan oleh semua bangsa Islam, kecuali Indonesia. Mulai Dakka di Bangladesh, sampai dengan Alhambra di Granada, Sevilla di Spanyol, semuanya dominan dengan kaligrafi dan arabesk. Dengan arabesk umat Islam melakukan permainan dan pengembangan konsep-konsep geometrik, karena umat Islam tidak bisa menggambar binatang. Karena itu, ada yang mengatakan seni Islam ini berkembang sebagai pelarian.

Tetapi ada juga yang tidak setuju bahwa seni kaligrafi adalah pelarian, dengan mengatakan bahwa itu adalah suatu kontinuitas positif dari tradisi membaca dan menulis berdasarkan kenyataan bahwa kitab suci pun disebut alQur'an yang berarti bacaan. Sehingga banyak orientalis yang mengatakan bahwa Islam adalah agama melek huruf. Begitu juga Arabesk yang tidak bisa seluruhnya ditafsirkan sebagai pelarian, karena al-Qur'an sendiri mengatakan bahwa Tuhan

Intizar, Vol. 22, No. 1, 2016 
itu tidak bisa digambar (QS. al-Ikhlas). Itu berarti wujud Tuhan tidak bisa digambar. Seperti ungkapan, laysa kamithlihi shay' (Tuhan itu tidak seperti apapun juga). Karena itu, kita tidak bisa menggambar Tuhan. Meskipun Tuhan adalah objek dari semua pernyataan devosional, namun umat Islam tidak bisa menjadikan Tuhan sebagai objek kesenian mereka, walaupun setinggi-tinggi aspek kesenian di muka bumi ini ialah yang menyangkut Tuhan.

Adapun yang cukup menarik untuk diteliti adalah program dakwah alQur'an al-Akbar Ukiran Palembang. Kedudukan seni kaligrafi dan desain dalam pembuatan mushaf al-Qur'an Ukiran Palembang ini, didasarkan kepada sebuah pandangan yang mengedepankan rekayasa budaya dalam tradisi suatu daerah. Pandangan yang terpenting adalah pengambilan desain dilandasi oleh tradisi dari masa lalu ke masa yang akan datang, bukan sebaliknya. Sebab, kedudukan dan fungsi al-Qur' an sebagai kitab suci umat Islam tidak akan dibatasi oleh ruang dan waktu, dengan tanpa mengurangi atau menghilangkan ciri khas dan keaslian sebuah hasil kebudayaan yang dijadikan ide dasar dalam pembuatan desain.

Oleh Karena itu, secara konsepsional, pembuatan mushaf al-Qur'an Ukir Khas Palembang sejatinya berlandaskan pada tiga hal, yaitu: Pertama, landasan etis, secara visual, seni rupa Islam melambangkan kesinambungan, konsistensi, keragaman, dan lain-lain, yang dilambangkan oleh berbagai macam bentuk keragaman budaya Palembang (seperti kerajinan tangan, seni ukir, dan pahat, arsitektur lokal, lambang kebesaran daerah, tanaman khas daerah, dan sebagainya).

Kedua, landasan filosofis, yang mengandung arti bahwa falsafah seni rupa Islam melambangkan kedalaman makna al-Qur'an yang menjadi landasan kehidupan dunia dan akhirat (keseimbangan). Serta mengandung arti bahwa secara fundamental seni kaligrafi Islam berpedoman kepada ayat-ayat al-Qur'an dan Hadits.

Ketiga, landasan estetis, yang mengandung arti bahwa Islam selalu identik dengan keindahan, sesuai dengan firman Allah Swt, bahwa Allah sangat mencintai keindahan, karena Dia adalah Dzat yang sangat indah. Oleh sebab itu kedudukan seni kaligrafi Al-Quran memiliki maqam yang tertinggi.

Keempat, tujuan pembuatan al-Qur'an al-Akbar Ukiran Khas Palembang ini adalah untuk mendakwahkan ajaran Islam ke masyarakat luas. ${ }^{6}$

Secara teoritis Islam memang tidak mengajarkan seni dan estetika (keindahan), namun tidaklah berarti Islam anti seni. Ungkapan bahwa Allah adalah jamîl (indah) dan mencintai jamal (keindahan) serta penyebutan Allah pada diriNya sebagai badi'us samawât al ardl.

Intizar, Vol. 22, No. 1, 2016 
Menurut Hidayat Nur Wahid, pembuatan Al-Quran al-Akbar ini adalah salah satu dakwah Islam melalui estetika. Ini menghadirkan semangat baru dalam menggali jejak-jejak peradaban Islam yang telah berlangsung lama. Sejak zaman dahulu, di hampir semua kerajaan Islam memiliki muatan corak mushaf al-Qur'an beraneka ragam. Tentunya dengan memperhatikan masa silam, kita memperoleh spirit dan kekuatan baru untuk meraih masa depan. ${ }^{7}$

Di berbagai negeri Islam, karya-karya seni sangat mencerminkan semangat tauhid. Dalam pengalaman Islam berbeda dari pengalaman Barat, seni tak pernah lepas dari agama. Seni Islam apapun bentuknya, akan memusatkan pikiran dan membangkitkan kekhusukan spiritual dalam mengagumi Sang Maha Pencipta. Semangat berkesenian (estetika) dalam pembuatan al-Qur'an al-Akbar ini sangat jelas mencerminkan ketauhidan itu. ${ }^{8}$

Sikap berkesenian dari semangat tauhid itu adalah kerakyatan. Estetika Islam berupa arsitektur, kaligrafi, maupun bangunan beribadah, memberi penghargaan kepada kerja kreativitas dan kolektivitas. Karena itu, mutu master piece yang terdapat pada pembuatan al-Qur'an al-Akbar, yang di dalamnya dikerjakan bersama (mulai penggagas, kaligrafer, tukang ukir, penghias, donatur, hingga pen-tashih), maka itu adalah bukti etos Islam yang memuliakan seni dalam kerja serius dan bernilai ibadah. ${ }^{9}$

Sedangkan menurut Sirajuddin AR, membincang kaligrafi sangatlah menarik karena inilah estetika Islam yang belakangan ini banyak menimbulkan greget. Begitu banyak ungkapan yang melukiskan (estetika) keindahan dan fungsi kaligrafi. Di Malaysia atau Brunei Darussalam disebut khat, bukan kaligrafi, agar lebih dekat dengan sumber aslinya, al-khat al-jamil (tulisan indah). Istilah kaligrafi itu sudah berbau Barat karena berasal dari bahasa Yunani, kalios (indah) dan graf (tulisan). ${ }^{10}$

Kedatangan agama Islam memberikan pengaruh luar biasa terhadap seni kaligrafi, terutama pengaruh al-Qur'an yang memberikan sentuhan pada setiap aspek kehidupan Muslim. Al-Qur'an mengangkat kaligrafi ke puncak seni yang tertinggi dan dianggap mulia. Oleh karena itu, antara kekuatan keimanan dan keindahan telah mendorong kaum Muslim untuk memperoleh sebuah tulisan (kaligrafi) dengan menyalin ayat-ayat al-Qur'an. ${ }^{11}$

Di Indonesia, seni melukis khat atau kaligrafi sudah lama dikenal, bahkan mungkin sejak kelahiran pesantren-pesantren perintis, seperti Pesantren Giri Kedaton, Pesantren Ampel Denta di Jawa Timur dan Pesantren Syekh Qura di Karawang, Jawa Barat. Tetapi pelajaran khat pada masa-masa itu masih sangat 
sederhana dan belum dijuruskan kepada penghayatan keindahan sebagaimana sekarang.

Masjid-masjid di Aceh, meskipun dibuatnya oleh Belanda, arsitekturnya sangat memperhatikan selera orang Aceh. Begitu juga masjid Sultan Deli yang menurut banyak orang adalah masjid yang paling indah di Timur Jauh. Tapi mulai dari Tapanuli Selatan sampai ke Jawa, semua arsitekturnya sangat lokal. Seandainya tidak karena ada mihrab, orang barangkali tidak mengenal bahwa itu adalah masjid. Kalau orang Arab, misalnya, masuk ke masjid Demak, barangkali ia tidak tahu bahwa itu adalah masjid. Padahal masjid merupakan wahana paling penting ekspresi seni Islam, seperti kaligrafi yang kemudian bisa digabung dengan arabesk, yaitu tema-tema ekspresi keindahan alam yang mempermainkan segi-segi tiga, empat, dan sebagainya.

Seni kaligrafi ditinjau dari falsafahnya adalah kelanjutan dari watak agama Islam sebagai agama melek huruf. Karena itu, kitab sucinya disebut al-Qur'an (bacaan), yang mengasumsikan bahwa setiap umat Islam harus pandai membaca. Tentunya, kalau pandai membaca dengan sendirinya juga harus pandai menulis. Karena itu, secara sosiologis agama Islam mempunyai reputasi sebagai agama yang selalu memperkenalkan tradisi membaca.

Sekarang, sebagian dari gaya kaligrafi yang semula berjumlah ratusan telah pupus. Kini tinggal beberapa gaya yang paling fungsional di dunia Islam,

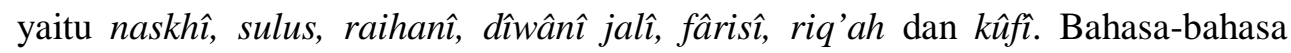
yang menggunakan kaligrafi Arab menurut catatan Muhammad Tahir Kurdi (penulis Mushaf Makkah al-Mukarramah) dan pengarang kitab Târîkh al-Khatt al 'Arabi) terdiri atas lima kelompok bahasa-bahasa Hindia termasuk Pegon atau Melayu, Jawi, kelompok bahasa-bahasa Persia, kelompok bahasa-bahasa Afrika, dan yang kelima, khusus bahasa Arab itu sendiri. ${ }^{12}$

Kaligrafi kontemporer yang banyak dimuat dalam aneka media terus dikembangkan dalam bentuk-bentuk kategori tradisional, figural, ekspresionis dan simbolis, dan acap kali mendobrak batas-batas baku dan klasik. Motif-motif pemberontakan atau memberontak yang menimbulkan keinginan uzlah (memisahkan diri) dari bentuk-bentuk baku dan klasik. Motif-motif pemberontakan sering tampak. Pertama, dalam pengolahan huruf-huruf yang menolak anatomi kaidah khat seperti yang dirumuskan Ibnu Muqlah, sehingga jenis khat-nya tidak mudah lagi diidentifikasi. Kedua, mempertahankan gagasan penggunaan khat baku, namun menempatkannya dalam variasi-variasi pengolahan yang beragam, sehingga sebuah karya tidak hanya selesai pada huruf, tetapi huruf-

Intizar, Vol. 22, No. 1, 2016 
huruf dikombinasikan lebih erat dengan latar belakangnya untuk alasan penyatuan (wahdah). ${ }^{13}$

Di Indonesia, corak kontemporer seperti ini sering diistilahkan dengan kata lukisan kaligrafi untuk membedakannya dengan kaligrafi murni yang telah dibakukan sejak zaman Ibnu Muqlah. Baik corak kaligrafi murni maupun lukisan kaligrafi, keduanya beriringan dan dianut oleh para khattât (penulis) dan seniman kaligrafi di Indonesia, yang menunjukkan apresiasi dan perhatiannya terhadap seni tersebut. $^{14}$

Selain faktor agama (al-Qur'an dan hadits), faktor-faktor lain yang mendorong tumbuh berkembangnya kaligrafi Arab adalah perluasan wilayah kekuasaan Islam dan sokongan kuat para penguasa dan ulama di mana berjayanya pemerintahan-pemerintahan Islam. Para khalifah atau raja Islam sejak masa kekhalifahan Bani Umayyah hingga masa akhir Kesultanan Turki Usmani adalah pelindung-pelindung gigih para kaligrafer yang memberi penghargaan besar setiap karya mereka.

Sementara itu, para ulama besar, seperti Hasan Basri, Ahmad Suhrawardi, dan Abdurrhaman Khawarizmi beperan besar dalam membentuk dan mengubah kaligrafi dari potongannya yang kuno menjadi tulisan yang sempurna dan indah, melengkapi dasar-dasar rumus Ibnu Muqlah. Begitu besarnya pengaruh al-Qur'an menyentuh setiap aspek kehidupan muslim sehingga mengangkat kaligrafi ke puncak seni yang dianggap suci. Oleh karena iman telah mendorong kaum muslimin memperelok kaligrafi dalam menyalin al-Qur'an, maka penamaan kaligrafi Islam (bukan kaligrafi Arab), menurut tokoh kaligrafi Libanon, Kamil Baba, dapat diterima, mengingat besarnya peranan Islam dalam usaha pengembangan kaligrafi Arab, maka dalam pelbagai literatur sebutan kaligrafi lebih populer daripada sebutan kaligrafi Arab.

Di Palembang, saat ini kita menyaksikan karya besar berupa kaligrafi AlQuran 30 juz dengan ukiran khas Palembang. Inilah hasil karya Syofwatillah Mohzaib, alumni Pondok Pesantren Ar-Risalah, Ponorogo, Jawa Timur. Sebuah kenyataan bahwa putra Indonesia mampu memiliki pencapaian gemilang, terutama dalam pengembangan kebudayaan dan seni kaligrafi al-Qur'an.

Dalam catatan sejarah, Palembang memiliki letak geografis yang sangat strategis. Palembang sudah sejak masa kuno menjadi tempat singgah para pedagang yang berlayar di Selat Malaka. Di kawasan ini pula menjadi tempat singgah para musafir yang beragama Islam yang oleh penguasa kala itu Raja Sriwijaya telah diterima dengan baik dan dapat menjalankan ibadah menurut 
agama Islam. Dari perlintasan dan pergaulan antar etnis inilah kebudayaan di wilayah ini berkembang seperti seni ukir, kuliner, dan arsitektur.

Maka, kehadiran al-Qur'an al-Akbar Ukiran Palembang ini sangat berarti bagi masyarakat Indonesia umumnya, dan bagi masyarakat kota Palembang khususunya. Mengingat kota Palembang sejak zaman dahulu itu dikenal memiliki banyak ragam kebudayaan, baik seni ukir maupun budaya lainnya. Al-Qur'an Ukir ini adalah terobosan baru dalam dunia seni dan kaligrafi al-Qur'an. Setidaknya ini akan mengulang kembali kejayaan Palembang.

Sebenarnya, penulisan mushaf al-Qur'an telah dimulai sejak abad ke-7. Pada tahun $652 \mathrm{M}$, pemerintahan khalifah Utsman bin Affan telah mengirimkan empat atau lima salinan al-Qur'an pertama ke beberapa wilayah Islam. Naskah tersebut dikenal dengan Rasm Utsmani. Naskah inilah yang kemudian menjadi standar baku penyalinan al-Qur' an pada masa-masa selanjutnya.

Seiring perkembangan peradaban Islam, dari Timur Tengah hingga Nusantara, penyalinan mushaf al-Qur'an menyesuaikan latar budaya dan kondisi zaman. Lokalitas budaya tempat mushaf disalin merupakan faktor yang ikut menentukan dan mempengaruhi variasi bentuk, motif, warna iluminasi, dan termasuk gaya kaligrafinya.

Dalam hal kaligrafi, keunikan mushaf Nusantara di antaranya tampak dalam karakter kaligrafi berhias, yaitu komposisi kaligrafi yang bermotif tetumbuhan. Kreativitas tulisan tersebut dituangkan khususnya pada kepala-kepala surah. Unsur kreativitas lokal itu, baik dalam iluminasi maupun kaligrafi, berkembang sangat leluasa dan berkarakter unik.

Sekitar abad ke-13, penyalinan al-Qur'an di Nusantara ditengarai dimulai dari Aceh, ketika Kerajaan Samudra Pasai sebagai kerajaan Islam tertua di Nusantara berdiri di bawah kepemimpinan Sultan Malik Saleh. Meski kita tidak menemukan salinan mushaf al-Qur'an khas Nusantara dari abad itu bisa jadi karena lekang dimakan zaman atau sebab lainnya tapi dengan adanya kerajaan Islam, secara otomatis naskah al-Qur'an menjadi prioritas utama.

Berikutnya, penyalinan al-Qur'an secara tradisional berlangsung sampai akhir abad ke-19 atau awal abad ke-20, yang berlangsung di berbagai kota atau wilayah penting masyarakat Islam kala itu, seperti Aceh, Riau, Padang, Palembang, Banten, Cirebon, Yogyakarta, Surakarta, Madura, Lombok, Pontianak, Banjarmasin, Samarinda, Makasar, Ternate, dan lain-lain.

Seiring dengan berkembangnya teknologi percetakan litografi (cetak batu), penyalinan al-Qur'an secara tradisional pelan-pelan mulai ditinggalkan. 
Tradisi seni mushaf yang telah berlangsung selama berabad-abad di Nusantara bisa dikatakan telah terhenti, dan beralih pada al-Qur'an versi cetak. Setelah kemerdekaan RI, dimulailah penulisan mushaf al-Qur'an Pusaka pada 23 Juli 1948 (17 Ramadhan 1367 H). Huruf ba' sebagai huruf pertama basmalah ditulis oleh Bung Karno, dan Mim sebagai huruf penghabisan ditulis oleh Bung Hatta. Mushaf tersebut berukuran $100 \times 200 \mathrm{~cm}$.

Karena distribusi al-Qur'an cetak awal (early printing) yang tidak merata di seluruh Nusantara, penyalinan al-Qur'an secara manual masih terus berlangsung sampai awal abad ke-20. Baru pada tahun 1991, saat pembuatan mushaf Istiqlal, era baru kreativitas seni mushaf tumbuh kembali. Proyek ini diprakarsai oleh beberapa ahli dai ITB Bandung, seperti Mahmud Buchari, AD Pirous, Ahmad Noe'man, dan beberapa sarjana serupa lainnya.

Sampai saat ini, ada beberapa mushaf dalam bentuk naskah asli dan cetakan, seperti mushaf Istiqlah (1990-1995), mushaf Sundawi Jawa Barat (19961997), mushaf Alm Hj. F. St. Hartinah Soehato mushaf Ibu Tien (1997-1999), mushaf Jakarta/DKI (1999-2002), Mushaf Kalimantan Barat (2001-2002), juz Amma PNRI (1999-2002). Mushaf Wakaf Berwajah Palembang Keluarga Alm. H. Syaiful Bahri B (2002), dan Mushaf al-Bantani (2010).

Berdasarkan hasil penelitian dan inventarisasi tentang al-Qur'an di berbagai daerah yang dilakukan oleh Badan Litbang dan Diklat Departemen Agama RI sejak tahun 2003 hingga tahun 2005 menyatakan, bahwa ragam mushaf al-Qur'an di Indonesia mencapai angka sekitar 300 mushaf.

Yang lebih menarik, perkembangan berikutnya adalah banyaknya salinan mushaf al-Qur'an dalam ukuran besar. Setidaknya terdapat tiga mushaf al-Qur'an yang dibuat versi besar itu, yakni mushaf al-Qur'an versi Wonosobo (1994) dengan ukuran lebar 1,5 $\mathrm{m}$ dan panjang $2 \mathrm{~m}$ atau 2 × $3 \mathrm{~m}$ bila dibuka, mushaf alQur'an versi Parung (2010) panjangnya mencapai 2 meter dan lebarnya 2,8 meter, dan al-Qur'an ukir versi Palembang (2012) yang dikenal "al-Qur'an al-Akbar" dengan ukuran tinggi mencapai 14 meter dan lebarnya 9,25 meter.

Sedangkan gagasan pembuatan al-Qur'an Terbesar ini tercetus pada tahun 2002, setelah penulis merampungkan pemasangan kaligrafi pintu dan ornamen Masjid Agung Sultan Mahmud Badaruddin II, Palembang, Sumatera Selatan. Dari sana terpikir untuk membuat mushaf al-Qur'an dengan ornamen dan ukiran khas Palembang. Maka di malam bulan Ramadhan, tergambar dalam pikiran penulis sebuah al-Qur'an raksasa yang terbuat dari kayu dan menjadi mushaf yang terbesar di dunia. ${ }^{15}$

Intizar, Vol. 22, No. 1, 2016 


\section{Ragam Mushaf al-Qur'an Nusantara}

Sebagai Kitab suci sampai akhir zaman, Allah Swt. telah menjamin otentisitas al-Qur'an. Jaminan itu, berupa kemudahan dalam variasi sistem hafalan, penyalinan, dan pengamalan al-Qur'an yang diwariskan secara turuntemurun sejak zaman Rasulullah SAW. Sebenarnya, penulisan mushaf al-Qur'an telah dimulai sejak abad ke-7. Pada tahun $652 \mathrm{M}$, pemerintahan khalifah Usman bin Affan telah mengirimkan empat atau lima salinan al-Qur'an pertama ke beberapa wilayah Islam. Naskah tersebut dikenal dengan "Rasm Usmani”. Naskah inilah yang kemudian menjadi standar baku penyalinan al-Qur'an pada masa-masa selanjutnya.

Dalam hal kaligrafi, keunikan mushaf Nusantara di antaranya tampak dalam karakter "kaligrafi berhias" atau "kaligrafi floral", yaitu komposisi kaligrafi yang bermotif tetumbuhan. Kreativitas tulisan tersebut dituangkan khususnya pada kepala-kepala surah. Unsur kreativitas lokal itu, baik dalam iluminasi maupun kaligrafi, berkembang sangat leluasa dan berkarakter unik, bahkan dalam bentuk makhluk zoomorphic seperti Macan Ali di Cirebon.

Sekitar abad ke-13, penyalinan al-Qur'an di Nusantara ditengarai dimulai dari Aceh, ketika Kerajaan Samudra Pasai sebagai kerajaan Islam tertua di Nusantara berdiri di bawah kepemimpinan Sultan Malik al-Saleh. Meski kita tidak menemukan salinan mushaf al-Qur'an khas Nusantara dari abad itu, bisa jadi karena lekang dimakan zaman atau sebab lainnya, tetapi dengan adanya kerajaan Islam, secara otomatis naskah al-Qur' an menjadi prioritas utama.

Sampai saat ini, mushaf al-Qur'an tertua di Nusantara diperkirakan dibuat pada tanggal 23 Oktober $1625 \mathrm{M}$ oleh Abdu as-Shufi ad-Din. Besar mushaf alQur'an yang terbuat dari kulit kayu ini adalah $25 \times 17 \times 6.5 \mathrm{~cm}$, dengan jumlah 769 halaman. Mushaf tersebut adalah milik Bapak Muhammad Zen Usman, Singaraja, Bali.

Ada satu catatan bahwa mushaf tertua ditulis oleh seorang ulama al-Faqih al-"Ali 'Afifuddin Abdul Baqi bin 'Abdullah al-'Adni pada tahun $1585 \mathrm{M}$ atau bertepatan dengan 7 Zulqaidah 1005 H, Mushaf Imam Muhammad Arikulapessy, imam pertama masjid Wapauwe, yang selesai ditulis pada tahun 1550, dan Mushaf Nur Cahya, seorang gadis cucu Imam Muhammad Arikulapessy, yang selesai ditulis pada tahun 1590. Kedua mushaf yang terakhir, masih tersimpan dengan rapi di Masjid Tua Wapauwe Kaitetu, Ambon dan sempat dipamerkan pada sebuah Festival Istiqlal di Jakarta, tahun 1991 dan 1995.

Intizar, Vol. 22, No. 1, 2016 
Penyalinan al-Qur' an secara tradisional ini berlangsung sampai akhir abad ke-19 atau awal abad ke-20, yang berlangsung di berbagai kota atau wilayah penting masyarakat Islam kala itu, seperti Aceh, Riau, Padang, Palembang, Banten, Cirebon, Yogyakarta, Surakarta, Madura, Lombok, Pontianak, Banjarmasin, Samarinda, Makasar, Ternate, dan lain-lain.

Mushaf al-Qur'an cetakan tertua di Indonesia, bahkan di Asia Tenggara diperkirakan dibuat pertama kali di Palembang, senin 21 Agustus $1840 \mathrm{M}$, oleh Bapak Ibrahim bin Husin (Singapura). Besar mushaf ini adalah $30 \times 20 \times 3 \mathrm{~cm}$, dengan jumlah 607 halaman. Kini, mushaf ini dipegang oleh Bapak H. Muhammad Azhari bin Kemas Haji Abdullah.

Setelah kemerdekaan RI, dimulailah penulisan mushaf Al-Qur'an Pusaka pada 23 Juli 1948 (17 Ramadhan 1367 H). Huruf Ba' sebagai huruf pertama basmalah ditulis oleh Bung Karno, dan Mim sebagai huruf penghabisan ditulis oleh Bung Hatta. Mushaf tersebut berukuran 100 x $200 \mathrm{~cm}$. Karena distribusi alQur'an cetak awal (early printing) yang tidak merata di seluruh Nusantara, penyalinan al-Qur'an secara manual masih terus berlangsung sampai awal abad ke-20. Baru pada tahun 1991, saat pembuatan Mushaf Istiqlal, era baru kreativitas seni mushaf tumbuh kembali. Proyek ini diprakarsai oleh beberapa ahli dari ITB Bandung, seperti Mahmud Buchari, Prof. AD Pirous, Ir. Ahmad Noe'man, dan beberapa sarjana serupa lainnya.

Sampai saat ini, ada beberapa mushaf dalam bentuk naskah asli dan cetakan, seperti Mushaf Istiqlah (1990-1995), Mushaf Sundawi Jawa Barat (19961997), Mushaf Alm Hj. F. St. Hartinah Soehato/Mushaf Ibu Tien (1997-1999), Mushaf Jakarta/DKI (1999-2002), Mushaf Kalimantan Barat (2001-2002), Zuz Amma PNRI (1999-2002). Mushaf Wakaf Berwajah Palembang Keluarga Alm. H. Syaiful Bahri B (2002), dan Mushaf al-Bantani (2010).

Keberadaan mushaf di berbagai wilayah dan lapisan masyarakat ini menunjukkan bahwa penyalinan al-Qur'an, baik secara tradisional maupun kontemporer, bisa dikatakan cukup merata di berbagai daerah, dalam bentuk yang beraneka rupa. Para penyalin mushaf itu, selain indah bertabur warna juga bertabur iluminasi dan kebudayaan daerah dari beberapa provinsi yang ada di tanah air.

Kehadiran ragam mushaf tersebut tentu saja mengundang apresiasi dari berbagai kalangan. Seorang intelektual Islam yang cukup terkenal, Syeyyed Hossein Nasr mahaguru Harvard University, Amerika Serikat, di sela-sela muhibahnya ke Indonesia tahun 1993, dia menyatakan rasa keharuan dan kegembiraannya bahwa sebuah mushaf yang begitu indah, yang pada abad ini 
seperti telah dilupakan oleh umat Islam, kini ternyata di buat di Indonesia. Dia mengatakan bahwa bila mushaf semacam ini dibuat di Timur Tengah, tentulah kita tidak perlu merasa heran karena sejarah mushaf adalah berasal dari sana.

Seorang cendekiawan lainnya dari Amerika Serikat, Kenneth George, pada tahun 1998 memperdalam penelitian tentang kebudayaan Indonesia yang bernafaskan Islam, saat itu ia mengajar di Universitas of Oregon, menulis sebuah artikel panjang mengenai al-Qur'an Mushaf Istiqlal dengan judul "Design on Indonesia's Muslim Communitie". Tulisan ini memperoleh sambutan hangat dari Association for Asian Studies.

Berdasarkan hasil penelitian dan inventarisasi tentang al-Qur'an di berbagai daerah yang dilakukan oleh Badan Litbang dan Diklat Departemen Agama RI sejak tahun 2003 hingga tahun 2005 menyatakan, bahwa ragam mushaf al-Qur'an di Indonesia mencapai angka sekitar 300 naskah.

\section{Proses Pembuatan al-Qur'an al-Akbar Ukiran Khas Melayu dari Palembang}

Pada tahun 2002, Syofwatillah Mohzaib (Opat) telah merampungkan pemasangan kaligrafi pintu dan ornamen Masjid Agung Sultan Mahmud Badaruddin II. Dari situ, ia mulai berpikir untuk membuat Mushaf al-Qur'an dengan ornamen dan ukiran khas Palembang. Pada malam di bulan Ramadhan, tergambar dalam pikiran Opat sebuah al-Qur'an raksasa yang terbuat dari kayu, seperti ukiran yang dibuatnya di masjid peninggalan Kesultanan Palembang Darussalam, dan menjadi mushaf yang terbesar di dunia.

Dengan niat ikhlas dan mengharap ridha Allah Swt. sebagai seorang yang cinta dengan seni kaligrafi dan ukiran khas Palembang, serta demi kelestarian seni ini, maka gagasan tersebut segera dikerjakan. Setelah selesai 1 keping lembaran kaligrafi al-Qur'an, ia memperlihatkannya kepada salah seorang tokoh Palembang, H. Murzuki Alie. Dengan harapan, beliau mau mengajak sahabat, dermawan, dan relasinya untuk mensponsori pembuatan al-Qur'an al-Akbar ini.

Tepat pada 1 Muharram 1423/15 Maret 2002, atas inisiatif H. Marzuki Alie dan pengurus Masjid Agung Palembang, terlihat 1 keping al-Qur'an Al-Akbar (Surat al-Fatihah) yang terbuat dari kayu tembesu berukuran $177 \mathrm{~cm} \mathrm{x} 140 \mathrm{~cm}$ dengan ketebalan 2,5 cm, dipajang pada acara bazar peringatan tahun baru Islam yang diketuai oleh H. Marzuki Alie sendiri.

Masalah dana tersebut akhirnya mendapat angin segar setelah bertemu dengan tokoh masyarakat asal Sumsel, Bapak Taufik Kiemas yang datang ke Masjid Agung. Kehadiran suami Presiden Megawati Soekarnoputri itu men-

Intizar, Vol. 22, No. 1, 2016 
support bantuan sebesar Rp 200 juta, sehingga al-Qur'an al-Akbar bisa segera dikerjakan.

Lalu, dibentuklah tim pembuatan al-Qur'an al-Akbar di Palembang. Panitia ini terdiri dari Pelindung dan Penasihat: H. M Taufik Kiemas, H. Rosihan Arsyad (Gubernur Sumatera Selatan kala itu), KH. Dr Kgs Oesman Said DSOG, H. Husni, dan Dr. H. Jalaluddin.

Untuk Dewan Pembina terdiri dari, KH. M. Zen Syukri, Dr. J. Suyuti Pulungan, Prof. Dr. Aflatun Mukhtar, Yayasan Masjid Agung Palembang, dan Yayasan Ahlul Quran. Sementara pengurus lainnya, Ketua Umum H. Ir. Bakti Setiawan, Ketua Harian H. Marzuki Alie, Sekretaris RHM Adi Rasyidi, dan Bendahara $\mathrm{Hj}$. Asmawati.

Kepanitiaan ini dibantu juga oleh beberapa seksi, seperti seksi dana diketuai H. Roni Hanan, seksi umum dan logistik diketuai HM. Noerdin, seksi humas dan promosi diketuai M. Syukri Ibn Soha, dan seksi pengawasan dan pelaksanaan teknis diketuai Syofwatillah Mohzaib.

Secara khusus untuk mengoreksi isi al-Qur'an tersebut, telah dibentuk tim pentashih yang beranggotakan ulama cukup berpengaruh di Sumatra Selatan. Mereka adalah KH. A. Sazily Mustafa (almarhum), KH. Kgs. Nawawi Dencik, KH. Abdul Qodir (almarhum), KH. Hasnuri Royani (almarhum), dan KH. Muslim Anshori, dibantu dosen IAIN Raden Fatah Drs. Sanusi Goloman Nasution.

Selama ini, proses pembuatan al-Qur'an raksasa dikerjakan di kediaman Syofwatillah, di Jalan Pangeran Sidoing Lautan Lr. Budiman, No. 1009 Kelurahan 35 Ilir Palembang. Menurut Syofwatillah, pembuatan al-Qur'an raksasa tersebut memang diperkirakan selesai 2004, tapi molor dari target karena terkendala dana dan bahan baku kayu tembesu.

Semula, harga kayu tembesu Rp 2 juta, kemudian mengalami kenaikan menjadi Rp 7 juta per kubik, dan melonjak lagi hingga Rp 10 juta per kubik. Padahal, anggaran kayu dan tinta yang tercantum pada proposal hanya Rp 2 juta per item. Mengenai hal ini, Syofwatillah tidaklah memikirkan atau menghiraukan untung rugi. Karena pembuatan al-Qur'an ini adalah "kerja amal" sehingga kendala tersebut niscaya yakin dapat teratasi dengan baik. Bagi Syofwatillah, ini adalah mahakarya dan menjadikannya sebagai lahan pengabdian bagi agama tercinta.

Pemilihan kayu tembesu sendiri bukan hanya membuat al-Qur'an dan menyiarkan islam saja, tetapi juga untuk mempromosikan Kota Palembang. Sebab, kayu jenis ini merupakan kayu asli Kota Palembang yang digabung dengan ukir 
khas Palembang juga. Di sisi lain, proses kreatifnya juga bisa dibilang rumit dan tidak bisa dikerjakan sendirian, melainkan perpaduan berbagai keahlian personil dalam tim. Sebelum diukir di atas papan, ayat-ayat al-Qur'an terlebih dahulu ditulis di atas kertas karton. Lalu, tulisan ini dijiplak ke kertas minyak. Sebelumnya, tulisan ayat al-Qur' an di atas karton ini dikoreksi oleh tim pentashih. Sehingga jika terjadi kesalahan, bisa langsung diperbaiki.

Kemudian, kertas minyak tersebut ditempel ke atas papan yang sudah disiapkan. Huruf-huruf di atas kertas minyak ini menjadi petunjuk bentuk huruf kaligrafi ayat al-Qur'an yang harus diukir. Dalam menulis kaligrafi ayat al-Qur'an dengan bentuk ukiran ini, Syofwatillah menggunakan Jenis huruf atau kaligrafi yang digunakan Khat Naskhi standar tulisan al-Qur'an, yang dijadikan standar terbitan Arab Saudi dan Kementrian Agama RI. Untuk tajwidnya, ia menggunakan tajwid standar Kementerian Agama RI. Untuk membingkai ayat-ayat al-Qur'an itu, di tepi lembar al-Qur'an raksasa dihiasi dengan ukiran ornamen khas Palembang.

Pada tahun 2008, pembuatan al-Qur'an ini telah rampung. al-Qur'an ini terdiri atas dua cover (sampul). Halaman 1-604 sebanyak 306 lembar terdiri atas juz 1-30. Sedangkan halaman 605-630 berisi 17 lembar yang di dalamnya berupa hiasan al-Qur'an, daftar isi, daftar halaman, tajwid, sambutan-sambutan, mukaddimah, pengesahan pentashih, panitia dan daftar donatur dan partisipan. Ukurannya tidak main-main, tebal keseluruhannya termasuk cover mencapai 9 meter. Pada hari Kamis 14 Mei 2009 dapat diluncurkan di Masjid Agung Palembang oleh Kepala Departemen Agama Provinsi Sumatra Selatan, H. Najib Hartawi yang dihadiri para hafizh dan hafizhah se-Sumatra Selatan.

Menurut Sofwatillah, al-Qur'an ukiran pertama terbesar di dunia yang terbuat dari kepingan kayu tersebut memiliki jumlah sebanyak 315 lembar kayu atau 630 halaman. "Ide pembuatan Al-Qur'an Al-Akbar sudah dimulai sejak bulan Ramadhan $1422 \mathrm{H}$ lalu, kemudian keping pertama dipamerkan pada 1 Muharam $1423 \mathrm{H}$ atau bertepatan 15 Maret 2002. Alhamdulillah, setelah hampir tujuh tahun penggarapan bisa selesai dan siap diluncurkan ke masyarakat," ujar Opat, sapaan akrab Syofwatillah Mohzaib.

Meskipun telah diluncurkan, tetapi hal itu guna dilakukan pengoreksian saja. Dan peluncuran kali ini adalah deteksi dini, dan bisa langsung diperbaiki. "Al-Qur'an ini belum diresmikan, tetapi baru diluncurkan guna dikoreksi. Rencananya, pembuatan selesai 2004 yang bersamaan dengan PON XVI. Akan

Intizar, Vol. 22, No. 1, 2016 
tetapi, karena banyak hambatan dan kendala, jadi molor tahun 2008 dari 2002 pembuatan," kata Opat.

Dalam penyusunan satu juz surah al-Baqarah di antaranya dipasang berupa kayu yang berdiri tegak membentuk lingkaran dari sepuluh lembar kayu ukir. Sedangkan lembaran lainnya masih terpisah-pisah disusun di atas rak membentuk labirin dengan jarak $50 \mathrm{~cm}$ antar lembar. Ini memungkinkan bagi pengunjung untuk ikut melakukan koreksi, bila mana ada kesalahan penulisan huruf atau tajwid.

Manusia adalah tempatnya salah dan khilaf. Setelah dilakukan koreksi dan dibaca berulang-ulang oleh para pakar tersebut, masih saja ada kekurangan huruf atau terbalik. Salah satunya ditemukan oleh KH. Dr. Hidayat Nur Wahid, Anggota DPR RI, saat berkunjung ke Palembang bersama rombongan Ketua DPR RI Dr. H. MArzuki Alie. Kesalahan tersebut segera diperbaiki.

Jadi, karya ini betul-betul dilaunching pertama dan terbesar dalam bentuk ukiran kayu yang digabung dengan seni khas Palembang. "Mantan ketua MPR RI, Hidayat Nur Wahid meminta untuk tidak menetapkan terlebih dahulu al-Qur' an ini terbesar di dunia. Sebab, di luar negeri juga ada. Akan tetapi, setelah beliau melihat langsung, maka beliau terkejut dan langsung mengakui karena ini memang besar, sementara yang di luar negeri bukan dibuat dengan kayu tetapi kertas," ujar Opat.

Masjid Agung adalah bagian dari bukti kejayaan Islam di Palembang berabad-abad lalu. Kini, Masjid Agung telah menjadi Masjid nasional. Sementara al-Qur'an raksasa yang digarap Sofwatillah yang juga menjadi penanggung jawab dalam pembuatan kaligrafi yang menghiasi Masjid Agung, akan menjadi bukti bahwa dari

Menurut Sofwatillah, yang punya keterampilan kaligrafi dengan belajar secara otodidak sejak duduk di MTsN Pakjo Palembang ini, penyelesaian alQur'an raksasa yang mengangkat seni kaligrafi al-Qur'an dan seni ukir khas ornamen Palembang, bukan hanya menjadi tanggung jawab dirinya. Tetapi tanggung jawab semua umat muslim di Sumatra Selatan. Kini, gagasan besar itu telah menjadi tanggung jawab seluruh masyarakat Palembang.

Pada tahun 2005, dana yang berhasil digalang oleh kepanitiaan mencapai Rp 800 juta. Sumbangan dana dari donatur tersebut semakin memacu semangat menyelesaikan al-Akbar yang akhirnya dapat selesai selama tujuh tahun. Biaya yang dikeluarkan untuk menciptakan karya spektakuler tersebut mencapai Rp 1,2 miliar.

Intizar, Vol. 22, No. 1, 2016 
Dari data yang ada, sedikitnya 30 penyumbang yang telah membantu di antaranya, H. M. Taufik Kiemas sebanyak 1 juz, Nazarudien Kiemas 1 juz, Gusti Bazan Kurnia 1 juz, M Yamin 1 juz Dodi Makmun Murod 1 juz, Dirut PT Danareksa 1 juz, PT Pusri 1 juz, Muda'i Madang 1/2 juz, H Husni (Walikota Palembang) 1 juz, Bupati Ogan Komering Ulu (OKU) Syahrial Oesman (mantan Bupati OKU dan mantan Gubernur Sumsel) 1 juz, PT Bukit Asam 1 juz, Menteri Agama Sayid Agil Al-Munawar 1 juz, Yani Arsyad (PT Jakarta Lyoid) 1 juz, Syarifudin Alambai 1 juz, H Heriyanto (PITI Palembang) 1 juz, Dandim 0418 Palembang Letkol ZL Amalsyah Tarmizi 1 lembar, dan H Rosihan Arsyad (yang saat itu Gubernur Sumatra Selatan) 1 juz.

Belakangan, daftar donatur bertambah menjadi 32 orang, dengan penambahan dari Bapak Susilo Bambang Yudhyono (Presiden RI), Alex Noerdin (Bupati Musi Banyuasin, sekarang Gubernur Sumatra Selatan), sehingga dana yang terkumpul mencapai Rp 931.000.000,-.

Salah satu mahakarya terbesar masyarakat Sumsel ini diresmikan langsung Presiden RI, Susilo Bambang Yudhoyono (SBY) pada tanggal 20 Januari 2012 yang bertepatan dengan dilaksanakannya konferensi 53 negara islam di Kota Palembang. Tidak hanya itu, al-Qur'an ini juga ditandatangani 53 presiden parlemen islam sedunia.

\section{Museum Bayt al-Qur'an al-Akbar Ukiran Kayu Khas Melayu Palembang}

Seiring dengan perkembangan teknologi, al-Qur'an memang sudah dapat dicetak ribuan lembar-lembar setiap hari. Pembuat al-Qur'an juga bukan hanya dari kalangan umat muslim, tetapi juga mereka yang non muslim dengan tujuan bisnis. Karenanya, menurut Syofwatillah, bukan tidak mungkin terjadi pemalsuan al-Qur'an. Apalagi dengan diberlakukannya pasar bebas, kita tidak mungkin mengecek secara teliti dan detail isi al-Qur'an yang masuk ke Indonesia. Apalagi beberapa tahun lalu diketahui adanya kesalahan-kesalahan pada produksi alQur'an impor. Tentunya, diperlukan rujukan guna menjaga otensitas al-Qur'an.

Dengan selesainya pembuatan al-Qur'an raksasa di Palembang ini, diharapkan bisa menjadi rujukan dari setiap al-Qur'an yang dicetak atau diterbitkan maupun al-Qur'an impor, sekaligus menjadi simbol Islam di Palembang khususnya, Sumatra Selatan bahkan Indonesia umumnya. Untuk itulah, dengan pembuatan Al-Qur'an Al-Akbar ini diharapkan setelah masuk MURI dan Guinnes of Record, juga menjadi rujukan bagi setiap pembuatan al-Qur'an.

Intizar, Vol. 22, No. 1, 2016 
Al-Qur'an al-Akbar ini pernah disimpan di salah satu ruangan di lantai tiga Masjid Agung Palembang. Bentuk bangunan yang unik, sangat layak untuk dikunjungi selain ibadah. Luas bangunannya 5.520 meter persegi dengan daya tampung 7.750 orang. Di sini diletakkan 315 keping al-Qur'an raksasa yang dibuat dengan kayu ukir tembesu kas Palembang, berwarna dasar cokelat dengan tulisan al-Qur' an timbul berwarna emas.

Tiap lembar ada ukiran motif kembang di bagian tepi. Warnanya juga kuning. Demikian memikatnya seni ukiran tersebut. Biasanya, al-Qur'an dibuat di atas kertas, kulit kayu, daun bahkan kulit binatang. Akan tetapi, inilah jadinya jika membuat al-Qur'an dengan syiar ditambah dengan seni. Hasilnya berupa AlAkbar, yakni nama al-Qur'an ukir kayu tembesu raksasa pertama di Indonesia, bahkan di dunia dengan menonjolkan budaya lokal.

Banyak pengunjung telah datang ke Masjid Agung Palembang, seperti dari Malaysia, Singapura, Iran dan lainnya. Namun, untuk mewujudkan hasil karya dan pikiran cerdas yang dicetuskan anggota DPR RI Syofwatillah Mohzaib hingga membuat masyarakat Sumsel bangga ini tidaklah mudah. Setidaknya butuh waktu tujuh tahun dan dana Rp 1,2 miliar lebih guna mewujudkan karya besar ini. Saat ini, Museum al-Qur'an al-Akbar berada di Komplek Pesantren IGM Ilksaniyah Gandus, Palembang.

Secara konstruksi, al-Qur'an al-Akbar ini disusun menjulang tinggi ke langit, di mana lembar-lembaran al-Qur'an tersusun rapi bertingkat. Akan disediakan lift untuk mencapai ketinggian yang diperkirakan sampai 25 Meter. Selanjutnya, telah dicatatkan pada Guinness Wolrd Record sebagai “al-Qur'an alAkbar di Dunia".

Setelah sekian lama al-Qur'an al-Akbar tersimpan, tentu ada kekhawatiran karya besar ini tidak terawat secara maksimal. Oleh karena itu, tebersit pemikiran untuk membangun sebuah museum, agar mahakarya ini menjadi bagian khazanah Nusantara yang dapat dibanggakan. Sebab, pada dasarnya museum dapat menjadi sarana belajar tanpa mengambil peran guru. Museum, di mana di dalamnya terdapat al-Qur'an al-Akbar akan menjadi bahan bacaan dan wisata rohani masyarakat, sebagai media pembelajaran yang sangat penting.

Museum untuk menyimpan mahakarya sebenarnya bukanlah hal yang asing di dunia Barat, meski hanya untuk benda-benda yang bersifat kesenangan dunia semata. Misalnya, patung lilin di London. Ini hanya berorientasi memajang patung-patung lilin yang persis seperti aslinya. Ada pula benda-benda di Museum of Death yang spesialisasi dalam semua hal yang mengerikan. Memiliki koleksi

Intizar, Vol. 22, No. 1, 2016 
permanen, termasuk kepala hasil pemenggalan oleh Henri Landru Désiré (The Bluebeard Paris). Tetapi, semua itu hanya replika yang dibuat agar menyerupai asli.

\section{Metode Dakwah Bayt al-Qur'an al-Akbar Ukiran Khas Melayu Palembang}

Kontribusi Bayt al-Qur'an al-Akbar Ukiran Khas Melayu Palembang terhadap peradaban Islam dapat dilihat dari beberapa aspek. Pertama, aspek religious, yaitu dakwah Islam melalui eksistensi Bayt al-Qur'an al-Akbar Ukiran Khas Melayu Palembang. Lembaran-Lembaran Kaligrafi al-Qur'an yang terdapat di Bayt al-Qur'an, telah menyuarakan wahyu Islam dan sekaligus menggambarkan tanggapan orang-orang Islam terhadap pesan Ilahi. Setiap titik-titik yang ditulis oleh kaligrafer menciptakan pola dasar surgawi tentang kaligrafi al-Qur'an dan juga garis-garis serta kandungan-kandungan hukum alam yang tidak hanya membentuk ruang angkasa, namun juga ruang arsitektur Islam.

Kemudian, melalui penulisan dan pembacaan huruf-huruf, kata-kata, dan ayat-ayat ini, manusia merasakan bahwa kalimat-kalimat al-Qur'an dalam bentuk kaligrafi bukan sekedar kalimat-kalimat yang memancarkan gagasan, namun juga memancarkan kekuatan dalam diri pembacanya. Kedua, aspek etika, yaitu kesadaran ritual keberagamaan. Melalui seni kaligrafi manusia dapat mengetahui hakikat yang maha kuasa. Nilai-nilai al-Qur'an yang diaplikasikan oleh para kaligrafer dapat membawa para pembacanya memahami dan memaknai kehidupan sesuai dengan ayat-ayat yang tertulis dalam kaligrafi.

Ketiga, aspek estetika, yaitu karya seni yang memuat nilai keindahan yang tinggi. Jika karya sastra menggunakan komunikasi verbal (diucapkan), karya seni banyak mengutarakan komunikasi nonverbal (diperlihatkan). Pesan dakwah jenis ini mengacu pada lambang yang terbuka untuk ditafsirkan oleh siapapun. Jadi, bersifat subjektif. Tidak semua orang mencintai atau memberikan apresiasi karya seni. Bagi pecinta karya seni, pesan dakwah jenis ini lebih banyak membuatnya berpikir tentang Allah SWT.

Syofwatillah dan kawan-kawan, dalam menjalankan misi dakwahnya agar sampai pada masyarakat adalah dengan membuat al-Qur'an dari Kayu Tembesu dengan corak ukiran khas Melayu Palembang. Tujuan pembuatan al-Qur'an menggunakan kayu tembesu ini, agar nilai-nilai keislaman bisa di transformasikan secara langsung dan mudah dipahami dan diterima oleh masyarakat Sumsel dan lainnnya. $^{16}$

Intizar, Vol. 22, No. 1, 2016 
Dari sini terlihat bagaimana Syofwatillah mempunyai strategi tersendiri dalam menjalankan kegiatan dakwahnya. Berdasarkan reportase penulis ke beberapa pengunjung yang datang ke lokasi al-Qur'an al-Akbar, kelebihan alQur'an ukiran khas melayu Palembang ini, teletak pada kemudahan pesan dan kesan yang disampaikan dalam al-Qur'an tersebut. Meski mempergunakan tulisan Arab dengan ukiran khas Palembang, tetapi para pengunjung dapat menyerapnya dengan mudah.

Tantangan dakwah pada era globalisasi menuntut adanya strategi dakwah yang profesional, bagi para da'i dengan memahami Islam secara komprehensif, terampil dalam menyampaikan pesan dakwah, dan memiliki kemampuan manajemen yang kuat, dalam melakukan kegiatan dakwah. Persoalan lain yang mesti diperhatikan dalam konteks dakwah di Indonesia ialah situasi kultural dan kemajemukan masyarakat. Keadaan demikian menuntut keterbukaan dan memperkenalkan Islam yang nonsectarian dan lebih dialogis dari para dai.

Oleh karenanya, salah-satu cara meningkatkan nilai-nilai spiritualitas dalam diri masyarakat dapat dilakukan, dengan cara melakukan wisata spiritual. Dengan memperkenalkan dan mengajak masyarakat mengunjungi tempat-tempat bersejarah para pejuang Islam, atau mengunjungi museum-museum yang bernilai religus. Dalam konteks Sumatera Selatan dapat dilakukan dengan mengunjungi tempat-tempat yang bernilai sejarah dan religius. Seperti mengunjungi Bayt alQur'an al-Akbar Ukiran Khas Melayu Palembang di Gandus.

Tentunya, eksistensi Bayt al-Qur'an al-Akbar Ukiran Khas Palembang di Gandus adalah salah satu upaya generasi saat ini, menghadirkan semangat dalam menggali jejak-jejak peradaban Islam yang telah berlangsung di Palembang. Sejak zaman dahulu, hampir semua kerajaan Islam memiliki masjid dan mushaf alQur'an beraneka ragam. Tentunya dengan memperhatikan dan mengunjungi ritusritus masa silam dan saat ini, kita memperoleh spirit dan kekuatan baru untuk meraih masa depan.

Di berbagai negeri Islam, karya-karya seni sangat mencerminkan semangat tauhid. Dalam pengalaman Islam berbeda dari pengalaman Barat, seni tak pernah lepas dari agama. Seni Islam apapun bentuknya, akan memusatkan pikiran dan membangkitkan kekhusukan spiritual dalam mengagumi Sang Maha Pencipta. Semangat berkesenian (estetika) dalam pembuatan al-Qur'an al-Akbar ini sangat jelas mencerminkan ketauhidan itu.

Oleh karena itu, penting bagi para orang tua, guru, pemerintah daerah dan pusat untuk mendukung kegiatan wisata spiritual dengan mengunjungi tempat- 
tempat pendidikan Islam yang unik. Di Palembang dapat dilakukan dengan mengunjungi Masjid Agung Palembang, Masjid Ki Merogan, Masjid Lawang Kidul, Masjid Chengho, dan museum Bayt al-Qur'an al-Akbar Ukiran Khas Palembang di Gandus. Bagi masyarakat, kegiatan ini selain meningkatkan spiritual juga dapat meningkatkan penghargan anak terhadap nilai-nilai luhur lokal (local wisdom). Sebab spirit Masjid Agung Palembang, Masjid Ki Merogan, Masjid Lawang Kidul, Masjid Chengho, dan pembuatan al-Qur'an al-Akbar ini berupaya mengimplemntasikan nilai-nilai kebenaran kesucian al-Qur'an juga melestarikan budaya Palembang.

Adapun tujuan dibuatnya Bayt al-Qur'an al-Akbar Ukiran Khas Melayu Palembang sebagai tempat wisata religi bertujuan untuk meningkatkan keimanan dan ketaqwaan umat Islam, terutama masyarakat Sumatera Selatan. Sedangkan misi dari Bayt al-Qur'an al-Akbar Ukiran Khas Melayu Palembang sebagai tempat wisata religi adalah untuk menyelenggarakan dan menyediakan tempat wisata religi yang dapat meningkatkan spiritualitas keagamaan masyarakat. ${ }^{17}$

Menurut pengakuan Bapak Omdut, salah satu hikmah terbesar yang didapat dari mengunjungi galeri al-Qur'an raksasa yang terdapat di kawasan Gandus ini adalah menimbulkan kekaguman yang luar biasa atas keindahan yang terpancar dari al-Qur' an raksasa ini. ${ }^{18}$

Bayt al-Qur'an al-Akbar yang lokasinya tidak jauh dari SD Negeri 169 Gandus, tepatnya berlokasi di Komplek Pesantren IGM Al-Ikhsaniyah Kecamatan Gandus, yang dipimpin oleh ustadz sekaligus politisi senayan Syofwatillah Mohzaib yang merupakan salah satu orang yang memprakarsai pembangunan alQur'an ukir raksasa ini. Telah banyak menginspirasi masyarakat luas untuk lebih dekat kepada Allah Swt, sepeti pengakuan Bapak Omdut di atas.

Sedangkan untuk menuju lokasi Bayt al-Qur'an Raksasa ini tidak begitu sulit. Wisatawan yang datang ke Palembang cukup dengan menyewa mobil angkot atau mobil plat hitam yang biasa mangkal di pasar 16 ilir atau dibawah jembatan ampera. Harga sewa mobil sekitar Rp.100.000,- (Seratus Ribu) rupiah untuk sekali antar. Bagi mereka yang bisa menawar, angkot tersebut cukup dibayar Rp.150.000 (Seratus Lima Puluh Ribu Rupiah) untuk antar dan jemput kembali ke Pasar 16 ilir. Layaknya kawasan wisata lainnya, Bayt al-Qur'an Raksasa ini juga menyediakan aksesories berupa baju kaos, gantungan kunci, stiker dan lan sebagainya, yang dapat dibeli di lokasi wisata sebagai buah tangan yang dapat dibawah pulang. Harga baju kaos berkisar Rp. 50.000 (Lima Puluh Ribu) sampai Rp. 100.000 (Seratus Ribu) perbuah. ${ }^{19}$

Intizar, Vol. 22, No. 1, 2016 
Pengunjung yang berdatangan ke Bayt al-Qur'an al-Akbar, bukan hanya berasal dari Kota Palembang, melainkan juga dari luar Kota Palembang, bahkan dari luar negeri. Astri, salah satu pengunjung yang berasal dari Banyuasin mengaku, sengaja meluangkan waktu tiap bulan Ramadhan untuk datang ke Bayt al-Qur'an al-Akbar dengan mengajak anak-anaknya. Menurutnya, selain untuk mengisi waktu dibulan puasa, juga mengharapkan dapat memberikan pelajaran tentang al-Qur'an kepada anak-anaknya. "Ya, memang tiap tahun saya sempatkan untuk ke sini, selain bisa liburan, anak-anak juga bisa mengetahui tentang alQur'an," kata Astri, Minggu, (21/6/2015). ${ }^{20}$

Selain itu, tepat di bawah al-Qur'an terdapat sebuah kolam yang lebih besar berisi ikan-ikan yang juga berukuran besar. Dijamin, anak-anak akan betah berada di sini. Di sudut lain galeri ada pusat penjualan cinderamata. Ruang shalat dan toilet juga tersedia di sini dan keadaannya cukup baik. Terdapat 315 potongan papan tembesu berukuran 177 × 140 sentimeter dimana dikedua sisinya diukir sehingga jumlah halamannya menjadi 630 halaman. Sudah cukup memuat 30 juz al-Qur'an. Bahan baku yang dibutuhkan untuk membuat al-Qur'an ini, kurang lebih 40 meter kubik kayu tembesu dimana hal tersebut membutuhkan biaya mencapai 2 miliar rupiah dan proses pengerjaan selama 7 tahun (dari tahun 2002 hingga 2008).

Indonesia dan Sumatera Selatan pada khususnya patut berbangga dengan keberadaan al-Qur'an ukir terbesar di dunia ini. Keberadaan Bayt al-Qur'an alAkbar ini tidak hanya menarik perhatian pengunjung lokal namun juga wisatawan dunia yang penasaran akan keberadaan al-Qur'an ukir ini. Sedangkan pengunjung yang datang ke Bayt al-Qur' an al-Akbar ini tidak dikenakan biaya. Bayt al-Qur'an al-Akbar dari waktu ke watu dapat menarik lebih banyak pengunjung. Saat ini, sudah menjadi salah satu objek wisata religi andalan Sumatera Selatan khususnya kota Palembang.

\section{Kesimpulan}

Berdasarkan uraian pada bab-bab sebelumnya, penulis dapat mengemukakan berapa hal sebagai kesimpulan akhir dan sekaligus sebagai jawaban terhadap permasalah yang dikaji dalam tulisan ini. Kesimpulan ini menegaskan dua hal pokok yakni metode dakwah kultural Bayt al-Qur'an alAkbar Ukiran Khas Melayu Palembang, dan aktivitas dakwahnya dalam kehidupan beragama di Sumatera Selatan.

Intizar, Vol. 22, No. 1, 2016 
Pertama, kontribusi Bayt al-Qur'an al-Akbar Ukiran Khas Melayu Palembang terhadap perkembangan metode dakwah kultural adalah dakwah melalui seni. Lembaran-Lembaran Kaligrafi al-Qur'an yang terdapat di Bayt alQur'an, telah menyuarakan wahyu Islam dan sekaligus menggambarkan tanggapan orang-orang Islam terhadap pesan Ilahi. Setiap titik-titik yang ditulis oleh kaligrafer menciptakan pola dasar surgawi tentang kaligrafi al-Qur'an dan juga garis-garis serta kandungan-kandungan hukum alam yang tidak hanya membentuk ruang angkasa, namun juga ruang arsitektur Islam.

Kedua, Bayt al-Qur'an al-Akbar Ukiran Khas Melayu Palembang sebagai tempat Wisata Religi yang sangat signifikan. Dengan memperkenalkan dan mengajak masyarakat mengunjungi tempat-tempat bersejarah para pejuang Islam, atau mengunjungi museum-museum yang bernilai religus. Dalam konteks Sumatera Selatan dapat dilakukan dengan mengunjungi tempat-tempat yang bernilai sejarah dan religius. Seperti mengunjungi Bayt al-Qur'an al-Akbar Ukiran Khas Melayu Palembang di Gandus.

Intizar, Vol. 22, No. 1, 2016 


\section{Endnote}

${ }^{1}$ Moh. Ali Aziz, Ilmu Dakwah, (Jakarta: Kencana Prenada Group, 2004), hlm. 330

${ }^{2}$ Muchlis M. Hanafi, Kenabian (Nubuwwah) dalam al-Qur'an, (Jakarta: Lajnah Pentashihan Mushaf al-Qur'an, 2012), hlm. xxiii

${ }^{3}$ Sayyid Quthub, at-Tashwi al-Fanni fi al-Qur'an, Penerjemah. Bahrun Abu Bakar, (Jakarta: Robbani Press, 2004), hlm. 14

${ }^{4}$ Nasaruddin Umar dkk, Jurnal Studi al-Qur'an, Vol. I, No. 1, (Jakarta: Pusat Studi al-Qur'an, 2006), hlm. 2

5 Budhy Munawar Rahman, "Dimensi Esoterik dan Estetik Budaya Islam.” Agama dan Pluralitas Budaya Lokal. (Surakarta: Universitas Muhammadiyah Surakarta, 2003), hlm. 101

${ }^{6}$ Wawancara pribadi dengan Syofwatillah Mohzaib Penggagas al-Qur'an al-Akbar Ukiran Khas Palembang, 10 November 2012

${ }^{7}$ Hidayat Nur Wahid, Kata Sambutan dalam Buku al-Qur'an al-Akbar Ukiran Khas Palembang, (Palembang: Jaringan Santri Indonesia, 2012), hlm. 6

${ }^{8}$ Ibid.,

${ }^{9}$ Ibid, hlm. 7

${ }^{10}$ Sirajuddin AR, Kata Sambutan dalam Buku al-Qur'an al-Akbar Ukiran Khas Palembang, (Palembang: Jaringan Santri Indonesi, 2012), hlm. 8

${ }^{11}$ Ibid.,

${ }^{12}$ Dewan Redaksi, Ensiklopedi Islam, (Jakarta: Ichtiar Baru van Hoeve, 1994), hlm. 6

${ }^{13}$ Ibid.,

${ }^{14}$ Ibid.,

${ }^{15}$ Wawancara pribadi dengan Syofwatillah Mohzaib Penggagas al-Qur'an al-Akbar Ukiran Khas Palembang, 10 November 2012

16 Wawancara pribadi dengan Syofwatillah, Pimpinan Pondok Pesantren IGM Palembang, 14 Agustus 2015

17 Wawancara pribadi dengan Syofwatillah, Pimpinan Pondok Pesantren IGM Palembang, 14 Agustus 2015

18 Omdut, Memandang Takjub al-Qur'an al-Akbar, artike diakses tanggap 20 Agustus 2015 dari http://omnduut.com/2014/12/08/memandang-takjub-bait-al-quran-alakbar/

${ }^{19}$ Muhammad Syukri Soha, "Wisata Religi Bayt Al Qur'an Al Akbar," artikel diakses tanggap 27 Agustus dari http://muhammadsyukrisoha.blogspot.co.id/2015/06/wisata-religi-bayt-al-quran-alakbar.html

20 “Al Quran Raksasa Ramai Dikunjungi di Bulan Ramadhan” artikel diakses tanggap 28 Agustus 2015 dari http://www. Ka bar pa lem bang.com/read-101-293-2015-06-21-alquran-raksasa-ramai-dikunjungi-di-bulan-ramadhan. html\#sthash.r2b3xzO0.dpuf

\section{Daftar Pustaka}

AR, Sirajuddin. (2012). Kata Sambutan dalam Buku al-Qur'an al-Akbar Ukiran Khas Palembang. Palembang: Jaringan Santri Indonesia. 
Aziz, Moh. Ali. (2004). Ilmu Dakwah. Jakarta: Kencana Prenada Group.

Dewan Redaksi. (1994). Ensiklopedi Islam. Jakarta: Ichtiar Baru van Hoeve.

Hanafi, Muchlis M. (2012) Kenabian (Nubuwwah) dalam al-Qur'an. Jakarta: Lajnah Pentashihan Mushaf al-Qur'an.

Muhammad Syukri Soha, "Wisata Religi Bayt Al Qur'an Al Akbar," artikel diakses tanggap 27 Agustus dari http://muhammadsyukrisoha. Blog spot.co.id/2015/06/wisata-religi-bayt-al-quran-al-Akbar.html

Omdut, Memandang Takjub al-Qur'an al-Akbar, artike diakses tanggap 20 Agustus 2015 dari http://omnduut.com/2014/12/08/memandang-takjubbait-al-quran-al-Akbarl

Quthub, Sayyid. (2004). at-Tashwi al-Fanni fi al-Qur'an, Penerjemah. Bahrun Abu Bakar. Jakarta: Robbani Press.

Rahman, Budhy Munawar. (2003). "Dimensi Esoterik dan Estetik Budaya Islam." Agama dan Pluralitas Budaya Lokal. Surakarta: Universitas Muhammadiyah Surakarta.

Umar, Nasaruddin dkk. (2006). Jurnal Studi al-Qur'an. Vol. I. No. 1. Jakarta: Pusat Studi al-Qur'an.

Wahid, Hidayat Nur Wahid. (2012). Kata Sambutan dalam Buku al-Qur'an alAkbar Ukiran Khas Palembang. Palembang: Jaringan Santri Indonesia.

Wawancara pribadi dengan Syofwatillah Mohzaib Penggagas al-Qur'an al-Akbar Ukiran Khas Palembang, 10 November 2012

Wawancara pribadi dengan Syofwatillah, Pimpinan Pondok Pesantren IGM Palembang, 14 Agustus 2015 